The Role of Health Consciousness, Food Safety Concern and Ethical Identity on Attitudes and Intentions towards Organic Food

\author{
Dr Nina Michaelidou \\ University of Birmingham \\ Birmingham Business School \\ University House \\ Edgbaston \\ Birmingham B15 2TT \\ Phone +441214148318 \\ n.michaelidou@bham.ac.uk
}

\author{
Dr. Louise M. Hassan \\ University of Stirling and the Open University \\ Institute for Social Marketing \\ University of Stirling \\ Stirling, FK9 4LA \\ Scotland UK \\ Phone +44 1786466457 \\ Fax+441786466449 \\ louise.hassan@stir.ac.uk
}




\begin{abstract}
The paper examines the roles of health consciousness, food safety concern and ethical self identity in predicting attitudes and purchase intention within the context of organic produce. A conceptual model is derived and tested via structural equation modelling. Findings indicate food safety as the most important predictor of attitude while health consciousness appears to be the least important motive in contrast to findings from some previous research. In addition, ethical self identity is found to predict both attitudes and intention to purchase organic produce emphasizing that respondents' identification with ethical issues affects their attitudes and subsequent consumption choices.
\end{abstract}

Key words: organic foods, health consciousness, food safety, ethical self-identity, structural equation modeling, attitudes and intentions, rural consumers.

\title{
Background
}

The organic food market has grown substantially over recent years across the globe (Giffort \& Bernard 2006; Padel \& Foster, 2005; Lockie et al. 2004). Several reasons have been proposed for this move towards purchasing organic within the literature from studies in the UK, Europe, Australia and the US. These include: a concern for health (Magnusson et al. 2003; Lockie et al. 2002; Grankvist \& Biel 2001; Magnusson et al. 2001; Wendel and Bugge 1997; Tregear et al. 1994), ethical, moral, political or religious motives (Honkanen et al. 2006; McEachern and McClean 2002), the quality or safety of conventional food produces (Giffort \& Bernard 2006; Baker et al. 2004; Makatouni, 2002;Williams \& Hammit 2001), environmental consideration (Lockie et al. 2004; Vindigni et al. 2002; Laroche et al. 2001; Schiffeerstein \& Oude Ophuis 1998; Grunert \& Juhl 1994; Sparks and Shepherd 1992) and personal values (Dreezens et al. 2005; Lea \& Worsley 2005). These reasons are often themed 
by existing literature into two broad categories (e.g. Padel \& Foster 2005; Wandel \& Bugge 1997) firstly consisting of individual or health (egoistic) motives and secondly, environmental and animal welfare (altruistic) (e.g. Magnusson et al. 2003) motives. Firstly, consumers perceive organic as a healthier alternative to conventional foods in that they contain more nutrients (Lea \& Worsley, 2005; Padel \& Foster, 2005; Baker et al. 2004; Lockie et al. 2004; Magnusson et al. 2001; Tregear et al. 1994) which enhance personal wellbeing (Williams and Hammit 2001). Organic produce is also considered safer (Padel \& Foster, 2005; Schifferstein \& Oude Ophuis, 1998), better in taste and more enjoyable than conventional products (Baker et al. 2004; Fotopoulos et al. 2003; Zanoli \& Naspetti, 2002; Roddy et al. 1996). Secondly, environmental sensitivity and animal welfare have also been found to motivate the purchase of organic produce (Magnusson et al. 2003; Schifferstein \& Oude Ophuis, 1998; Vindigni et al. 2002). Research has also focused on examining the effects of motives, beliefs and values on attitudes towards organic produce, purchase intentions and/or purchase frequency, reporting mixed results (e.g. Honkanen et al.2006; Padel and Foster 2005; Magnusson et al. 2003; 2001). For example, Magnusson et al. (2003) found health to be the stronger predictor of attitudes and purchase intention towards organic foods compared to environmental motives. In contrast, Honkanen et al. (2006) found that environmental and animal motives have a strong influence on attitudes. Similarly, previous studies indicate health to be the predominant motive for purchasing organic food and shaping attitudes (Schifferstein \& Oude Ophuis, 1998) however, Tarkiainen and Sundqvist (2005) refute health as a predictor of attitudes towards organic foods. Further, Baker et al (2004) found discrepancies in the motives explaining attitudes towards organic foods between UK and German consumers. In addition to the conflicting findings, extant research has focused on examining specific motives and their effect on purchase intention and frequency (e.g. Tarkiainen and Sundqvist 2005; Magnusson et al. 2003) omitting others, such as food safety 
and its role as a predictor of attitude and intention. In a similar line, the role of ethical self identity as an antecedent to attitude and intention has not been explored in the context of organic purchases despite its contribution in predicting attitudes and intention in similar contexts (Shaw \& Shiu, 2002a; Shaw \& Clarke, 1999; Sparks \& Shepherd 1992). These gaps in the literature highlight that our understanding of the role of motives that underlie attitudes and intention towards organic produce is still underdeveloped (Newsom et al. 2005). This study contributes to understanding the motives behind the purchase of organic produce by clarifying the roles of health consciousness, food safety concern and ethical self identity in predicting attitudes and intention. In particular, we focus on health consciousness in an attempt to clarify its value in predicting attitudes and purchase intentions towards organic produce, given the conflicting findings reported in the literature (e.g. Magnusson et al. 2003; Tarkiainen and Sundqvist 2005 etc.).Concurrently we attempt to clarify the role of food safety concern and ethical self identity in shaping attitudes and intentions, which have been omitted in the context of organic food purchase. We therefore simultaneously model health consciousness, food safety concern and ethical self identity together with an attitude to intention relationship. The following section discusses the research hypotheses. The methodology is then addressed and findings are presented. A discussion follows with implications for future research.

\section{Development of Research Hypotheses}

\section{Health Consciousness}

Health consciousness assesses the readiness to undertake health actions (Becker et al. 1977). Health conscious consumers are aware and concerned about their wellness and are motivated to improve and/or maintain their health, and quality of life to prevent ill health by engaging in healthy behaviours and being self-conscious regarding health (Newsom et al. 2005; Kraft \& 
Goodell, 1993; Plank \& Gould, 1990; Gould, 1988). Such individuals tend to be aware of and involved with nutrition and physical fitness (Kraft \& Goodell, 1993). Previous research has identified interest in health as a primary motive for the purchase of organic food (Lockie et al. 2002; Grankvist \& Biel 2001). In addition, health consciousness has been found to predict attitudes, intention and purchase of organic foods (Magnusson et al. 2003; 2001) since organic produce buyers are aware that food intake affects their health, they appreciate healthy and natural foods and are willing to switch foods to improve their health (Schifferstein \& Oude Ophuis, 1998). Although the relationship between health consciousness and attitude has not been supported in all studies (Tarkiainen \& Sundqvist, 2005) we nonetheless hypothesise that,

H1a: Health consciousness will positively affect attitude toward organic produce

H1b: Health consciousness will positively affect purchase intention of organic produce

\section{Ethical Self Identity}

An ethical or green consumer is ecologically conscious and buys products that are environmentally friendly and not harmful to the environment or society (Laroche et al. 2001; Harper \& Makatouni, 2002). Ethical motives were found to affect demand for organic foods and include concerns over the environment, the threat to animals, the threat to human life and the publicity over the heightened use of genetically modified crops fed to animals (McEachern \& McClean, 2002; Hartman \& Wright, 1999). In addition, Magnusson et al. (2003) and Honkanen et al. (2006) found that ethical motives explain attitude and intention towards organic produce. However, ethical motives may result in empathy and the subsequent formation of positive attitudes towards ethical issues (e.g. animal welfare) 
resulting in ethical consumption choices (Shaw \& Shiu 2002b). In this sense, ethical motives may become part of consumers' self identity (Shaw et al. 2000). Self identity is defined as the pertinent part of an individual's self that relates to a particular behaviour (Conner \& Armitage, 1998) and has been previously found to affect attitudes and intention in the purchase of fair trade groceries (Shaw \& Shiu, 2003, 2002a, 2002b). In the context of organic produce, we believe that the purchase of organic produce may be an expression of ethical behaviour and therefore we hypothesise that,

H2a: Ethical self identity will positively affect attitude towards organic produce

H2b: Ethical self identity will positively affect purchase intention of organic produce

\section{Food Safety Concern}

Organic buyers are equally concerned about the physical risks involved in the consumption of foods (Yee et al. 2005; Angulo et al. 2003; Zanoli \& Naspetti, 2002; Brom 2000; Williams \& Hammitt, 2000; Verbeke and Viaene 1999). Food safety represents consumers' concern of residues in food resulting from chemical sprays, fertilizers, artificial additives and preservatives and is often linked to farming methods (Yee et al. 2005). Although food safety incorporates other elements such microbiological safety and animal disease-related safety (e.g. BSE, Foot \& Mouth etc), the scarce research on food safety in the context of organic food conceptualizes food safety in terms of pesticide residues, hormones and natural toxins (e.g. Canavari et al 2002; Honkanen et al. 2006). Consumers seem to think of food safety in terms of additives, chemicals and preservatives in vegetables, fruits and processed foods which represent a constant safety issue in food production, as opposed to animal diseaserelated safety (e.g. Bird Flu etc) which is not constantly in the media. Further, Williams and Hammitt found that consumers believe organically grown produce poses fewer risks to consumers than conventional food products. Specifically, respondents believed that lower- 
pesticide-related mortality risks are associated with the consumption and production of organically grown produce. Similarly, Schifferstein and Oude Ophuis (1998) found that organic produce buyers are concerned about the safety of foods in that they are willing to sacrifice money in return (also Krystallis et al. 2006). In a related study concerning the purchasing of value-based fresh meat products, McEachern and Schroder (2004) found that views on meat safety had a role in shaping attitudes, perception of difficulties in terms of labelling and purchase behaviour. Despite food safety being highlighted by previous literature as a motive for purchasing organic food (e.g. Padel and Foster, 2005; Baker et al. 2004; Schifferstein \& Oude Ophuis, 1998) its relationship with attitudes and intention towards organic foods is yet to be formally modelled. Food safety is likely to be an important predictor of attitudes and purchase intentions towards organic produce, hence we hypothesize that:

H3a: Food safety concern will positively affect attitude toward organic produce

H3b: Food safety concern will positively affect purchase intention of organic produce

\section{Attitude and Intention}

In line with the Theory of Planned Behaviour (Ajzen, 1991; Azjen \& Fishbein, 1980), attitudes have been shown to have strong correlational relationships with behaviour and behavioural intention in multiple contexts (e.g. Choo et al. 2004; Shaw \& Shiu, 2002a; Shaw et al. 2000; Kalafatis et al. 1999; Sparks et al. 1995). In the context of organic food purchases, Magnusson et al. (2003, 2001) and Tarkiainen and Sundqvist (2005) found attitudes to explain purchase intention. In line with this research we hypothesize that:

H4: Attitude toward organic produce will positively affect purchase intention 
The aforementioned hypotheses are formally presented via the conceptual model below. This model depicts health consciousness, ethical self identity and food safety concern as antecedents of attitude toward organic produce. Attitude towards organic produce and ethical self identity are predicted to be antecedents of intention. The preceding sections discuss the methodology and findings of the study.

Figure 1: Conceptual Model

\section{Methodology}

Data were collected from a convenience sample of 222 consumers from the Island of Arran in Scotland during December 2003 using a self-completion questionnaire. The Island of Arran has over 5,000 inhabitants and one main town with several villages and hamlets around its peninsular. The Island has one main supermarket and a collection of smaller retail outlets. A regular ferry service runs from the main town of Brodick to the mainland (Scotland) and the journey lasts approximately 55 minutes. The self-completion questionnaire was administered in several locations around the Island including at the major supermarket. In addition a large number of participants were recruited on the ferry, however the researcher used filter questions to only recruit participants who lived on the Island. Where possible the researcher selected every fifth person leaving the main supermarket and approached as many people on the ferry crossings as possible. The researcher approached consumers on both crossings from the mainland and crossings to the mainland on four separate occasions. The target sample was 200 questionnaires. The sample comprises 159 (72\%) females, were the majority of the sample where the main purchasers of food for their household $(73 \%)$, with most of the 
sample in employment (82\%). Around one third of the sample have dependents aged under 16 years living at home with $68 \%$ married or living with a partner. The respondents' age ranged from 15 to over 65 years. The survey instrument was based on prior literature with attitude and intention measures developed based on Ajzen (1991), while ethical self identity was adapted from Shaw and Shiu (2003). The measure of food safety concern was adapted from measures contained in Roddy et al. (1996), and health consciousness was measured using the scale developed by Gould (1988). Appendix 1 gives details of the questionnaire measures employed.

\section{Results}

Reliability and validity

Table 1 provides Cronbach alpha values for the scales and factor analysis results. The alpha values are all above the recommended level of 0.7 (Hair et al. 1998). In addition, exploratory factor analyses for each scale revealed that each construct is unidimensional with over $50 \%$ of the variance explained, with the scree plots indicating one dominant factor for each construct. Table 2 provides means and standard deviations of the scales, as well as correlations between the constructs. A Confirmatory Factor Analysis (CFA) was then undertaken and yielded excellent fit $\left(\chi^{2}=51.341 \mathrm{df}=44 \mathrm{p}\right.$-value $=0.208 \mathrm{TLI}=0.995 \mathrm{CFI}=$ 0.996 RMSEA $=0.027$ AIC $=119.341)$ according to the usual conventions $(\mathrm{Hu} \&$ Bentler, 1999; Carmines \& McIver, 1981). All paths within the CFA model were significant $(p<$ $0.001)$

\section{Structural Model Analysis}

The conceptual model was then analysed, to determine if attitudes mediate the relationship between food safety concern (FSC), health consciousness (HC), ethical self identity (ESI) and 
intention. According to Baron and Kenny (1986) and Holmbeck (1997) four conditions must hold in a test of mediating effects. These are 1) the predictor variables (FSC, HC and ESI) significantly impact the mediator (attitude) in the expected direction, 2) the mediator (attitude) significantly impacts the dependent construct (intention) in the expected direction, 3) the predictor variables (FSC, HC and ESI) significantly impact the dependent construct (intention) in the expected direction, and 4) after controlling for the effects of the mediator (attitude), the impact of the predictor variables (FSC, HC and ESI) on the dependent construct (intention) is not significantly different from zero (for full mediation) or significantly reduced (for partial mediation). Results of these tests on each construct revealed that FSC and HC are fully mediated by attitude and ESI is partially mediated. The results of the final model are provided in Table 3. Overall the model fit is excellent with all paths between the indicators and their respective construct significant $(p<0.001)$. The model performs adequately with an $\mathrm{R}^{2}$ value of 0.49 for intention and 0.35 for attitude.

\section{Table 1}

Table 2

\section{Table 3}

\section{Hypotheses Testing}

In terms of the hypotheses developed, 5 of the 7 hypotheses are supported empirically; table 4 provides a summary of the results. Support is not found for H1b and H3b, relating to the 
relationship between FSC and HC and intention, however in both cases attitude played a crucial mediating role. Overall these results suggest that ethical self identity and food safety concern are very important factors in shaping attitude with ethical self identity also influencing intention. Health consciousness has only a small role in shaping attitude.

\section{Table 4}

\section{Discussion}

Extant research highlights health consciousness as the most important motive for explaining attitudes and behaviour towards organic foods (Padel \& Foster, 2005; Baker et al. 2004; Magnusson et al. 2003; Zanoli \& Naspetti, 2002; Wandel \& Bugge, 1997; Tregear et al. 1994). In contrast to this stream of research and in accordance with Tarkiainen and Sundqvist (2005) and Brunso \& Scholderer (2001), findings in this study indicate health consciousness to be the least important motive shaping attitudes towards organic produce in relation to ethical self identity and food safety concern. In addition, the relationship between health consciousness and intention is not significant. Unlike previous research these findings may suggest that although respondents are conscious about their health and possibly alert to any changes and responsible for the state of their health, they associate fewer health benefits (e.g. health preservation, health improvement) with organic produce with little to no influence on motivation to purchase. On the other hand, food safety concern is found to be one of the most important predictors of attitudes, but not intention. This indicates that respondents' favourable attitudes towards organic produce are critically formed from their concern over the safety of foods; particularly over residues in food from fertilizers, artificial additives, preservatives and chemical sprays. However, food safety concern does not directly predict intention to purchase organic produce. This indicates that this factor exerts only an indirect 
impact on intention and hence is not as strong an influence within the overall model. Exploring the total effects reveals that ethical self identity has a much stronger influence on purchase intention (0.62 for ethical self identity versus 0.31 for food safety concern). In contrast to health consciousness (total effect 0.16 on intention) and food safety concern, ethical self identity was found to explain both attitude and intention towards organic produce. This finding is in line with previous research on the purchase of fair trade groceries (Shaw \& Shiu, 2002a) and highlights that ethical issues may lead individuals to form favourable attitudes towards organic produce which in turn lead to stronger motivations to consume. Specifically, where ethical issues become central to the individuals' self identity this would result in both attitude and intention being adjusted accordingly (Shaw \& Shiu, 2002a), as shown in this study. The findings may reflect that the effect of egoistic motives such as healthiness and food safety on attitude and intention towards organic foods maybe declining whereas, altruistic motives such as ethical considerations currently appear more pertinent in shaping attitudes and intentions in the organic food context. However, only 35\% of attitude was explained by the three factors (ethical self identity, food safety concern and health consciousness), consequently respondents may perceive organic foods as no better than conventional foods with regard to other purchasing criteria, including for example taste, longer shelf-life, quality or overall perceived value (Fotopoulos \& Krystallis 2002; Magnusson et al. 2001). These factors have not been specifically modelled and may add to further explaining attitude. One further limitation is that the population contained only rural consumers a further study should seek to explore a more generalisable population. Rural consumers, have different views and attitudes towards food and shopping as previous research has shown (Broadbridge and Calderwood, 2002; McEachern and Warnaby, 2006; Skerratt, 1999). Rural communities also have less access to fresh produce such as fruit and vegetables which is a major issue as organic foods are known to have less shelve-life than 
conventional food and therefore small local retailers maybe reluctant to stock such items. In addition offering a choice between organic and conventional produce would result in restricted produce offerings as limited shelving space is taken up with similar organic and conventional product lines. Therefore the findings of this study are not generalisable to a wider population group which should be the focus of future research. One further limitation is the use of a self-selecting sample which may introduce bias into the research findings, however the researcher conducting the study tried to limit this by selecting possible participants at random and trying to encourage all passengers on the ferries to participate in the study.

\section{Conclusion and Implications}

Previous research reports mixed results about the effect of motives on attitudes and purchase intentions towards organic produce. Authors report both significant and insignificant relationships (e.g. Tarkiainen \& Sundqvist, 2005; Magnusson et al. 2003) highlighting that our understanding of the role of motives (e.g. health consciousness, food safety) underpinning consumption of organic produce remains to some extent elusive. The research reported in this paper contributes to knowledge by first studying self identity in the context of organic produce and second by simultaneously modelling health consciousness, food safety concern and ethical self identity as predictors of attitudes and intention towards organic produce. The findings reported in this study are important in furthering our understanding of the role of health consciousness, food safety concern and ethical self identity in the purchase of organic produce. Findings indicate food safety concern and ethical self identity as the most important predictors of attitudes towards organic produce. Food safety concern has to date received little research attention in the area of organic foods, given the findings in this study future research could explore this construct in other related contexts. Food safety concern is 
also pertinent to researchers studying consumer trust as it may be considered one of its dimensions towards choosing conventional, organic or health foods. Similarly, ethical self identity, although omitted by previous research as a motive affecting attitudes was found to predict both attitudes and behavioural intention highlighting the need to explore the role of this construct further in consumer decision making. Ethical self identity may be relevant as a construct in multiple contexts including for example behaviours relating to the use of renewable energy and carbon offsets. Further, findings in this study show health consciousness to be the least important motive in predicting attitudes toward organic produce. This finding provides some support to previous research (Magnusson et al. 2003) which indicate that health consciousness is a motive for shaping attitudes towards organic produce, and at the same time contradicts Tarkiainen and Sundqvist (2005) who refute health as a predictor of attitudes towards organic foods. However, this finding may indicate that the value of health consciousness as a motive to purchase organic food is declining. Individuals seem to be now driven by other motives to purchase organic produce including food safety and ethical concerns. There is therefore a need for research to move away from 'egoistic' motives which may have initially explained organic food purchase and focus more on 'altruistic' reasons which may explain and predict consumption of organic produce better. In this sense, altruistic motives may be the focus of future research in similar, contexts including pro-environmental behaviours such as consumption of renewable energy and recycling. Overall, these findings indicate that ethical consumers and those concerned about food safety are more likely to develop positive attitudes and intentions towards organic foods, than health conscious consumers. This may also have implications for advertisers of organic produce since organic consumption is shown to equally depend on ethical values and food safety. These perceived benefits should be highlighted when marketing organic food products to consumers. 


\section{Appendix 1: Measures}

Purchase Intention (7-point 0 to 6 scale, higher values indicate stronger purchase intention)

I intend to purchase organic food produce within the next fortnight (Not at all to Definitely)

I want to purchase organic food produce within the next fortnight (Definitely do not to

Definitely)

How likely is it that you will purchase organic produce within the next fortnight. (Not at all likely to Very likely)

Attitude toward Organic Food Produce (7-point +3 to -3 scale, higher values indicate a more favourable attitude)

Favourable / unfavourable

Positive / negative

Ethical Self Identity (7-point +3 to -3 strongly agree to strongly disagree scale, higher values indicate a stronger ethical concern)

I think of myself as someone who is concerned about ethical issues

I think of myself as an ethical consumer

Food Safety Concern (7-point +3 to -3 strongly agree to strongly disagree scale, higher values indicate a stronger concern for food safety)

Nowadays most foods contain residues from chemical spays and fertilisers 
I'm very concerned about the amount of artificial additives and preservatives in food The quality and safety of meat nowadays concerns me

Health Consciousness (7-point +3 to -3 strongly agree to strongly disagree scale, higher values indicate greater consciousness about health)

I reflect about my health a lot

I'm very self conscious about my health

I'm alert to changes in my health

I'm usually aware of my health

I take responsibility for the state of my health

I'm aware of the state of my health as I go through the day 


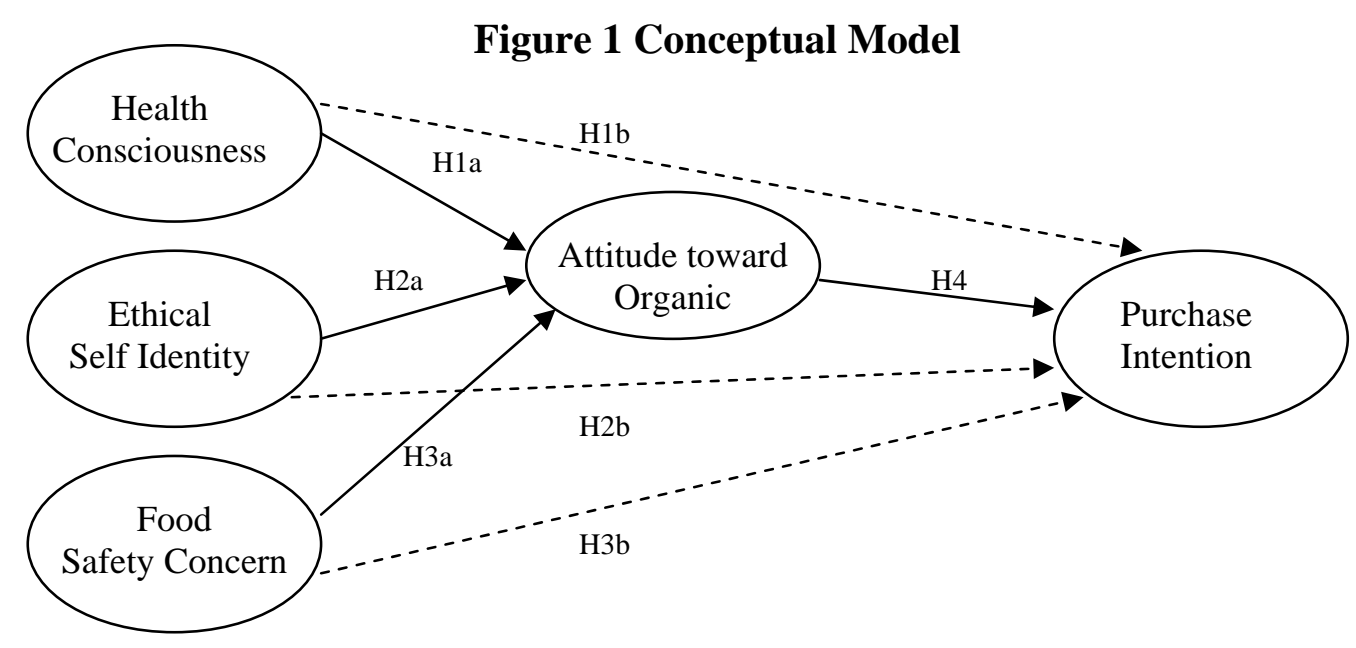

Table 1 Reliability and factor analysis results

\begin{tabular}{lcccc}
\hline \multicolumn{1}{c}{ Variable } & $\begin{array}{c}\text { No. of } \\
\text { items }\end{array}$ & $\begin{array}{c}\text { Alpha } \\
\text { (Corr) }\end{array}$ & $\begin{array}{c}\text { \% variance } \\
\text { extracted }\end{array}$ & $\begin{array}{c}\text { Eigen value } \\
\text { (range of loadings) }\end{array}$ \\
\hline 1. Purchase Intention & 3 & 0.96 & 93.31 & $2.78(0.95$ to 0.98) \\
2. Attitude toward Organic & 2 & $0.97(0.94)$ & 96.78 & $1.94(0.98)$ \\
3. Ethical Self Identity & 2 & $0.87(0.77)$ & 88.40 & $1.77(0.94)$ \\
4. Food Safety Concern & 3 & 0.70 & 62.99 & $1.89(0.78$ to 0.83) \\
5. Health Consciousness & 6 & 0.89 & 64.98 & $3.90(0.68$ to 0.85) \\
\hline
\end{tabular}

Table 2 Descriptive statistics

\begin{tabular}{lcccccc}
\hline Variable & Mean (SD) & 1 & 2 & 3 & 4 & 5 \\
\hline 1. Purchase Intention & $3.24(2.12)$ & 1 & & & & \\
2. Attitude toward Organic & $1.62(1.44)$ & 0.67 & 1 & & & \\
3. Ethical Self Identity & $1.35(1.27)$ & 0.50 & 0.49 & 1 & & \\
4. Food Safety Concern & $1.76(1.19)$ & 0.40 & 0.50 & 0.45 & 1 & \\
5. Health Consciousness & $1.74(1.02)$ & 0.23 & 0.33 & 0.30 & 0.31 & 1 \\
\hline
\end{tabular}

Table 3 Results of the Final Model

$\mathrm{R}^{2}$ (Intention) $=0.49 \mathrm{R}^{2}$ (Attitude) $=0.35$

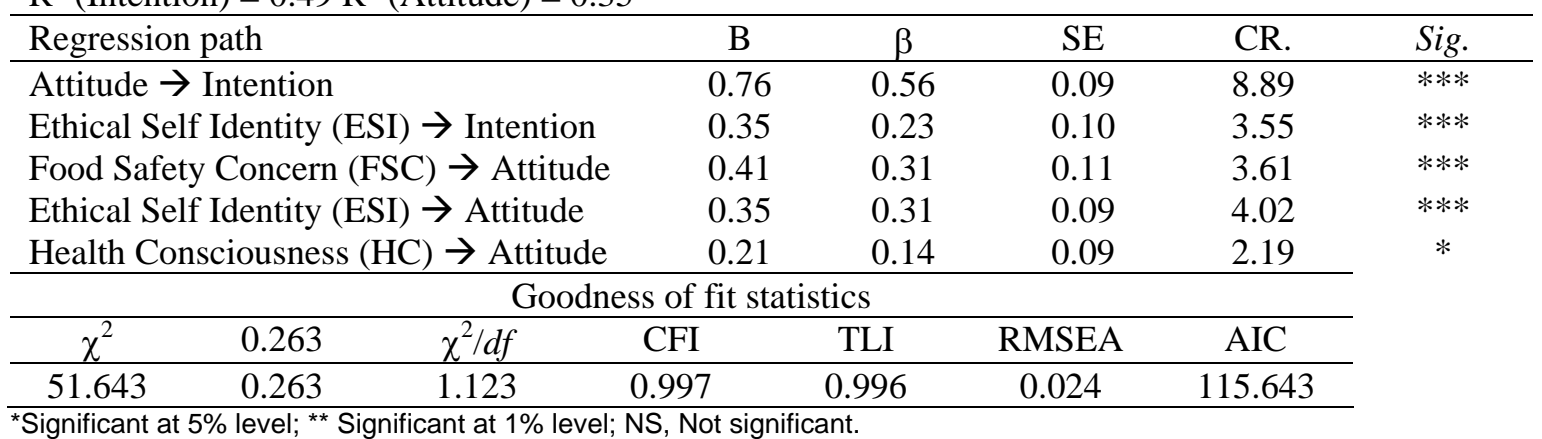


Table 4 Summary of results

\begin{tabular}{clc}
\hline Hypothesis & \multicolumn{1}{c}{ Predicted effect } & $\begin{array}{c}\text { Confirmed } \\
\text { (Yes/No) }\end{array}$ \\
\hline H1a & Health consciousness will affect attitude toward organic produce & Yes \\
H1b & Health consciousness will affect purchase intention of organic produce & No \\
H2a & Ethical self identity will affect attitude towards organic produce & Yes \\
H2b & Ethical self identity will affect purchase intention of organic produce & Yes \\
H3a & Food safety concern will affect attitude toward organic produce & Yes \\
H3b & Food safety concern will affect purchase intention of organic produce & No \\
H4 & Attitude toward organic produce will affect purchase intention & Yes \\
\hline
\end{tabular}




\section{References}

Ajzen, I. (1991).The theory of planned behaviour. Organisational Behaviour and Human Decision Processes, 50 (2), 179-211.

Ajzen, I., \& Fishbein, M. (1980) Understanding attitudes and predicting social behaviour. Englewood-Cliffs, NJ: Prentice-Hall.

Angulo, A. M., Gil, J. M., \& Tamburo, L. (2003) Foods safety and consumers’ willingness to pay for labelled beef in Spain. Paper presented at the $83^{\text {rd }}$ EAAE Seminar, Chania, 4-6 September (www.maich/eaae.gr).

Baker, S., Thompson, K. E., \& Engelken, J. (2004) Mapping the values driving organic food choice. European Journal of Marketing, 38 (8), 995-1012.

Baron, R. M., \& Kenny, D. A. (1986) The Moderator-mediator variable distinction in social psychological research: conceptual, strategic, and statistical considerations. Journal of Personality and Social Psychology, 51, 1173-1182.

Becker, M. H., Maiman, L. A., Kirscht, J. P., Haefner, D. P., \& Drachman, R. H. (1977) The health belief model and prediction of dietary compliance: a field experiment. Journal of Health and Social Behaviour, 18, 348-366.

Broadbridge, A., \& Calderwood, E. (2002) Rural grocery shoppers: do their attitudes reflect their action? International Journal of Retail and Distribution Management, 30 (8), 394-406. 
Brom, F. W. A. (2000) Food, consumer concern and trust: food ethics for globalizing market. Journal of Agricultural and Environmental Ethics, 12 (2), 127-139.

Brunso, K. \& Scholderer, J. (2001) Consumer health consciousness and the organic food boom: fact or fiction. Appetite, 37, 130.

Canavari , M., Guido, M. B., Spadoni, R., Regazzi, D. (2002) Food safety and organic fruit demand in Italy. British Food Journal, 104 (3/5), 220-232.

Carmines, E. G., \& McIver, J. P. (1981) Analyzing models with unobserved variables. In: Social measurement: Current issues (ed. By G. W. Bohrnstedt, \& E. F. Borgatta) Sage, Beverly Hills, USA

Choo, H., Chung, J.-E., \& Pysarchik, D. T. (2004) Antecedents to new food product purchasing behaviour among innovator groups in India. European Journal of Marketing, 38 (5/6), 608-625.

Conner M., \& Armitage, C. J. (1998) Extending the theory of planned behaviour: review and avenues for further research. Journal of Applied Social Psychology, 28, 1429-1464.

Dreezens, E., Martijn, C., Tenbult, P., Kok, G., de Vries N. K. (2005) Food and values: an examination of values underlying attitudes towards genetically modified- and organicallygrown food products. Appetite, 44 (1), 115-122. 
Fotopoulos, C., Krystallis, A. (2002) Organic product avoidance. Reasons for rejection and potential buyers' identification in a countrywide survey. British Food Journal, 104 (3-5), 233-260)

Fotopoulos, C., Krystallis, A., \& Ness, M. (2003) Wine produced by organic grapes in Greece: using means-end chains analysis to reveal organic buyers purchasing motives in comparison with the non-buyers. Food Quality and Preference, 14 (7), 549-566.

Gifford, K. \& Bernard, J. C. (2006) Influencing consumer purchase likelihood of organic food. International Journal of Consumer Studies, 30 (2), 155-165.

Gould, S. J. (1988) Consumer attitudes toward health and health care: a differential perspective. The Journal of Consumer Affairs, 22 (1), 96-118.

Grankvist, G., Biel, A. (2001) The importance of belief and purchase criteria in the choice of eco-labelled food products. Journal of Environmental Psychology, 21, 405-410.

Grunert, S. C., Juhl, H. J. (1995) Values, environmental attitudes and buying organic foods. Journal of Economic Psychology, 16, 36-62.

Hair, J. F., Anderson, R. E., Tatham, R. L., \& Black, W. C (1998) Multivariate Data Analysis. Prentice Hall International, Hemel Hempstead.

Harper, G. C., \& Makatouni, A. (2002) Consumer perception of organic food production and farm animal welfare. British Food Journal, 104 (3-5), 287-299. 
Holmbeck, G. N. (1997) Toward terminological, conceptual, and statistical clarity in the study of mediators and moderators: examples from the child-clinical and paediatric psychology literatures. Journal of Consulting and Clinical Psychology, 65, 599-610.

Honkanen, P., Verplanken, B., \& Olsen S. O. (2006) Ethical values and motives driving organic food choice. Journal of Consumer Behaviour, 5 (5), 420-431.

Hu, L., \& Bentler, P. M. (1999) Cutoff criteria for fit indexes in covariance structure analysis: conventional criteria versus new alternatives. Structural Equation Modelling, 6, 1-55.

Kalafatis, S., Pollard M., East, R., \& Tsogas, M. H. (1999) Green marketing and Ajzen’s theory of planned behaviour: a cross-market examination. Journal of Consumer Marketing, 16 (5), 441-460.

Kraft, F. B., \& Goodell, P. W. (1993) Identifying the health conscious consumer. Journal of Health Care Marketing, 13 (3), 18-25.

Krystallis, A., Fotopoulos, C. \& Zotos, G. (2006) Organic consumers profile and their willingness to pay (wtp) for selected organic food products in Greece. Journal of International Consumer Marketing, 19 (1), 87-97

Laroche, M., Bergeron, J., \& Barbaro-Forleo, G. (2001) Targeting consumers who are willing to pay more for environmentally friendly products. The Journal of Consumer Marketing, 18 (6), 503-520. 
Lea, E., \& Worsley, T. (2005) Australians’ organic food beliefs, demographics and values. British Food Journal, 107 (10/11), 855-869.

Lockie, S., Lyons, K., Lawrence, G., \& Grice, J. (2004) Choosing organics: a path analysis of factors underlying the selection of organic food among Australian consumers. Appetite, 43, 135-146.

Lockie, S., Lyons, K., Lawrence, G., \& Mummery, K. (2002) Eating green: motivations behind organic food consumption in Australia. Sociologia Ruralis, 42 (1), 23-40.

Makatouni, A. (2002) What motivates consumers to buy organic food in the UK? Results from a qualitative study. British Food Journal, 104 (3-5), 345-352.

Magnusson, M. K., Avrola, A., Hursti Koivisto U. K., Aberg, L, \& Sjoden, P. O. (2003) Choice of organic foods is related to perceived consequences for human health and to environmentally friendly behaviour. Appetite, 40, 109-117.

Magnusson, M. K., Avrola, A., Hursti Koivisto U. K., Aberg, L, \& Sjoden, P. O. (2001) Attitudes towards organic foods among Swedish consumers. British Food Journal, 103(3), 209-226.

McEachern, M. G., \& McClean, P. (2002) Organic purchasing motivations and attitudes: are they ethical? International Journal of Consumer Studies, 26 (2), 85-92. 
McEachern, M. G., \& Schroder, M. J. A. (2004) Integrating the voice of the consumer within the value chain: a focus on value-based labelling communications in the fresh-meat sector. Journal of Consumer Marketing, 21 (7), 497-509.

McEachern, M. G., \& Warnaby, G. (2006) Food shopping behaviour in Scotland: the influence of relative rurality. International Journal of Consumer Studies, 30 (2), 189-201.

Newsom, J. T., McFarland, B. H., Kaplan, M. S., Huguet, N., \& Zani, B. (2005) The health consciousness myth: implications of the near independence of major health behaviours in the North American population. Social Science \& Medicine, 60, 433-437.

Padel, S. \& Foster, C. (2005) Exploring the gap between attitudes and behaviour: understanding why consumers buy or do not buy organic food. British Food Journal, 107 (8), 606-626

Plank, R. E., \& Gould, S. J. (1990) Health consciousness, scientific orientation and wellness; an examination of the determinants of wellness attitudes and behaviours. Health Marketing Quarterly, 7 (3-4), 65-83.

Roddy, G., Cowan, C. A., \& Hutchinson, G. (1996) Consumer attitudes and behaviour to Organic foods in Ireland. Journal of International Consumer Marketing, 9 (2), 41-63.

Schifferstein, H. N. J., \& Oude Ophuis P. A. M. (1998). Health-related determinants of organic food consumption in the Netherlands. Food Quality and Preference, 9 (3), 119-133. 
Shaw, D. S., \& Clarke, I. (1999) Belief formation in ethical consumer groups: an exploratory study. Marketing Intelligence and Planning, 17 (2), 109-119.

Shaw, D. S., \& Shiu, E. (2003) Ethics in consumer choice: a multivariate modelling approach. European Journal of Marketing, 37 (10), 1485-1498.

Shaw, D. S., \& Shiu, E. (2002a) The role of ethical obligation and self-identity in ethical consumer choice. International Journal of Consumer Studies, 26 (2), 109-116.

Shaw, D. S., \& Shiu, E. (2002b) An assessment of ethical obligation and self-identity in ethical consumer decision-making: A structural equation modelling approach. International Journal of Consumer Studies, 26 (4), 286-293.

Shaw, D. S., \& Shiu, E., Clarke, I. (2000) The contribution of ethical obligation and selfidentity to the theory of planned behaviour: an exploration of ethical consumers. Journal of Marketing Management, 16, 879-894.

Skerratt, S. (1999) Food availability and choice in rural Scotland: the impact of "place”. British Food Journal, 101 (7), 537-544.

Sparks, P., \& Shepherd, R. (1992) Self identity and the theory of planned behaviour: assessing the role of identification with green consumerism. Social Psychology Quarterly, 55 (4), 388-399. 
Sparks, P., Shepherd, R., \& Frewer L. J. (1995) Assessing and structuring attitudes towards the use of gene technology in food production: the role of perceived ethical obligation. Basic and Applied Social Psychology, 16 (34), 267-285.

Tarkiainen, A., \& Sundqvist, S. (2005) Subjective norms, attitudes and intentions of Finnish consumers in buying organic food. British Food Journal, 107 (11), 808-822.

Tregear, A., Dent, J. B., \& McGregor, M. J. (1994) The demand for organically-grown produce. British Food Journal, 96 (4), 21-26.

Verbeke W. A. J. \& Viaene, J. (1999) Ethical challenges for livestock production: meeting consumer concerns about meat safety and animal welfare. Journal of Agricultural and Environmental Ethics, 12 (2), 141-151.

Vindigni, G., Janssen, M. A., \& Jager, W. (2002) Organic food consumption: a multitheoretical framework of consumer decision making. British Food Journal, 104 (8/9), 624642.

Wandel, M., \& Bugge, A. (1997) Environmental concern in consumer evaluation of food quality. Food Quality and Preference, 8 (1), 19-26.

Williams, P. R. D., \& Hammitt, J. K. (2001) Perceived risks of conventional and organic produce: pesticides, pathogens and natural toxins. Risk Analysis, 21 (92), 319-330. 
Williams, P. R. D., \& Hammitt, J. K. (2000) A comparison of organic and conventional fresh produce buyers in Boston Area. Risk Analysis, 20 (5), 735-746.

Yee, W. M. S., Yeung, R. M. W. \& Morris J. (2005) Food safety: building consumer trust in livestock farmers for potential purchase behaviour. British Food Journal, 107 (10/11), 841854.

Zanoli, R., \& Naspetti, S. (2002) Consumer motivations in the purchase of organic food: a means-end approach. British Food Journal, 104 (8), 643-653. 